\title{
Innovative activity and some features of taxation
}

\author{
Lyudmila Pushkareva ${ }^{1,2}$, and Mikhail Pushkarev ${ }^{2,3, *}$ \\ ${ }^{1}$ North-West Institute of Management, branch of RANEPA, 199178, Sredny prospect VO, 57/43, St. \\ Petersburg, Russia \\ ${ }^{2}$ Saint Petersburg State University of Architecture and Civil Engineering, 190005, 4 Vtoraya \\ Krasnoarmeiskaya, Saint Petersburg, Russia \\ ${ }^{3}$ Saint-Petersburg State Institute of Technology, 190013, 26 Moskovsky prospect, St. Petersburg, \\ Russia
}

\begin{abstract}
Innovation activity at an industrial enterprise is a set of conditions affecting the relationship of the interaction of the business structure with other business entities and the state. The environment of innovative activity at the enterprise is variable, heterogeneous, dependent on many positive or negative factors acting on it. The ratio of these factors makes the environment either favorable, i.e. conducive to the implementation of entrepreneurial innovative ideas or adverse (risky) for the normal development of innovation. In the coming years, the structure of sources of financing technological innovation in industry will not change significantly, therefore it is important to create such conditions for organizations so that they can finance innovation in the future. In this significant role belongs to taxes. There are a number of articles in the Tax Code, a slight change of which will create a more favorable climate for innovation. In some cases, it is important for a taxpayer to receive a deferral or installment plan for a tax payment. Investment tax credit also represents a deferred payment; it can be granted to organizations that perform R\&D; either technical re-equipment of own production; or carry out innovative or innovative activities, including creating new or improving applied technologies, etc.
\end{abstract}

\section{Introduction}

The term "innovation" and "innovation activity" currently occupy significant positions in the vocabulary of scientists and specialists, and in the entrepreneurial and managerial environment have acquired special significance. It should be noted that today, in terms of innovative terminology, various definitions appear.

In the regulatory legal acts of the Russian Federation, the term innovation has the following meaning: innovation, innovative product, new developments - a consequence of innovation, the result of which is a new product, service, technology or the emergence of a new technological form that has clear qualitative advantages when used. [1,2]

\footnotetext{
*Corresponding author: malexpush@bk.ru
} 
Financing technological innovation in industry is a strategic objective of any economy. This problem is especially relevant for the Russian economy in the context of the economic crisis and the processes of import substitution.

The innovative development of industry, which is a prerequisite for the development of an effective economy, presupposes the dominance of science in production and social spheres, which provides the basis for the transition to a real post-industrial level of development of society.

For the successful functioning and development of industrial enterprises, institutional conditions are necessary, which is ensured by the creation of a favorable business environment and entrepreneurship infrastructure [3-5].

\section{Methods}

During the study, a synthesis and analysis of theoretical and practical material was carried out, the results of previously performed studies were studied. Based on the information received, practical recommendations have been developed to improve the efficiency of innovation in an industrial enterprise.

The analysis made it possible to highlight an important criterion for the effectiveness of innovation in an industrial enterprise - stimulating taxation, to consider the specifics of taxation in innovation, to identify patterns that occur in the process of formation of innovation in an industrial enterprise.

The study showed that today, despite some experience in the development and implementation of innovations, the mechanism for the effective functioning of innovation in industrial enterprises is still far from its ideal option, as a result of which the author made practical suggestions.

The business environment, including innovative processes, the tax climate, etc., is a set of conditions that affect the relationship of interaction (direct and indirect) of the business structure with other market entities and the state. The business environment is unstable, heterogeneous, dynamically changing, depending on many positive or negative factors acting on it.

The ratio of these factors makes the business environment either favorable, i.e. contributing to the implementation of entrepreneurial functions and the progressive development of the entrepreneurial structure, or creating obstacles to the successful functioning of enterprises and their effective development. [1,6]

The development of the Russian industry requires serious technological solutions, so in engineering for the food industry there is a difficult technological situation. 270 enterprises are operating in this sector of the economy (not counting small enterprises). Innovative technologies and modern equipment use a small number of these enterprises.

Most enterprises in the industry mainly work on imported equipment. Some industries today almost entirely work on imported equipment. For example, the share of imported equipment in the meat industry is $-94 \%$, in the sugar industry- $81 \%$, at dairy enterprises $70 \%[7,8]$.

Statistics show that the financing of technological innovations in industry was carried out mainly at the expense of the organizations' own funds and amounted to $83.3 \%$ of the total financing in 2007 and $73.3 \%$ in 2017. Budget financing (financing from budgets all levels) during this time increased from $4.1 \%$ in 2007 to $7.5 \%$ in 2017 [8].

Most likely, in the coming years the structure of funding sources will not change significantly, therefore it is important to create such conditions for organizations so that they can finance innovations in the future. In this significant role belongs to taxes [9-11].

So, at present, when making charitable payments, including for conducting scientific research, the payer - an individual - has the right to reduce the tax base on the tax on 
personal income by donations, but not exceeding $25 \%$ of the amount of income received in the tax period and taxable.

Organizations have the right to allocate part of the proceeds to the formation of funds to support scientific, scientific, technical and innovative activities, created in accordance with the Federal Law "On Science and the State Scientific and Technical Policy" in an amount not exceeding $1.5 \%$ of sales revenue. Deductions exceeding the specified limit do not reduce the tax base for income tax.

Having removed the noted limitations, it is hoped that funding for innovation will increase. The Tax Code of the Russian Federation contains a number of articles, a slight change of which will create a more favorable climate for innovation.

So, for a taxpayer it is important in some cases to receive a deferral or installment plan of tax payment. Investment tax credit also represents a deferred payment; it can be granted to organizations that perform $\mathrm{R} \& \mathrm{D}$; either technical re-equipment of own production; or carry out innovative or innovative activities, including creating new or improving applied technologies, etc.

An investment tax credit is such a change in the tax payment deadline in which the organization, given the existing conditions, has the prospect of minimizing its tax payments within a certain period and within certain limits, followed by phased payment of the loan amount and accrued interest. Investment tax credit can be provided for income tax, as well as for regional and local taxes [12,13].

An organization included in the corresponding register of residents of the territorial development zone, an investment tax credit can be granted on more favorable terms, namely, the amount of expenses on capital investments in the acquisition, creation, reconstruction of depreciable property used for investment projects. In this case, interest on the loan amount is not charged.

By the Decree of the Government of the Russian Federation of April 10, 2013 No. 326, 20 entities were identified on whose territory the formation of territorial development zones is possible, but further work has not yet been carried out; the register of residents of the territorial development zone has not been determined [14].

In accordance with the Federal Law of 11.16.2011. No. 321-Ф3 Russian organizations can be combined into a consolidated group of taxpayers (CGT) for the purpose of calculating and paying income tax, taking into account the total financial result of economic activity, i.e. The income tax base is calculated as the sum of all income minus all expenses taken into account when calculating income tax $[15,16]$.

A consolidated group of taxpayers can be created by organizations if the following conditions are met:

- CGN can be created provided that one organization directly and (or) indirectly participates in the authorized (joint-stock) capital of other organizations and the share of such participation in each such organization is at least $90 \%$;

- for the organizations included in the group of companies, the total amount of value added tax, excise taxes, corporate income tax and mineral extraction tax paid during the calendar year preceding the year of submission of the documents on the creation of the CTG is at least 10 million. rub.;

- the total revenue in the previous year is not less than 100 billion. rub.;

- the total amount of assets according to the financial statements compiled as of December 31 of the previous year is 300 billion rubles.

Thus, a large organization can "surround" itself with small enterprises that carry out innovative activities, and which, due to the peculiarities of this activity, can be unprofitable if they function independently. But if such a small enterprise is included in the CTG, it will not be unprofitable in accordance with tax legislation [17].

Consider what benefits are provided by tax legislation for innovative income tax. 
Currently, R\&D expenses are taken into account in that reporting period in which individual stages or work as a whole were completed. The costs associated with the implementation of R\&D according to the list established by the Government of the Russian Federation can be taken into account by the taxpayer for profit tax purposes with a coefficient of 1.5 .

As noted in Art. 259 of the Tax Code, the taxpayer has the right to apply a raising factor to the basic depreciation rate, but not higher than 3 in respect of fixed assets used only for the implementation of scientific and technical activities. The use of a raising coefficient reduces the tax base for income tax, as a result, the taxpayer benefits. An increase factor is not applied to intangible assets.

If during the implementation of intangible assets resulting from $R \& D$, a loss is received, it is not taken into account for tax purposes and, therefore, increases the tax base. Thus, in relation to intangible assets, there are no benefits [18].

If upon sale of depreciable property, i.e. fixed assets and intangible assets, a loss is received, for tax purposes, it is included in other expenses and accounted for in equal installments over the term, defined as the difference between the useful life of this property and the actual life of its operation until the time of sale. In this case, taking into account the time factor, the amount of expenses for the period under consideration will be underestimated, or, what is the same, the tax base will be overstated. A similar approach, i.e. distribution of expenses for several periods in the Tax Code is not the only one. So, in accordance with Art. 2681 upon receipt of the economic object as a property complex, the amount of the paid premium to the price shall be recognized as an expense for 5 years from the period following the month when the ownership of the acquirer of the enterprise is registered.

The discount received by the buyer is recognized as income in the month when the registration of ownership. A price premium is the excess of the purchase price over the value of net assets. The discount to the price is the excess of the value of the net assets over the purchase price [19].

Similarly, for tax purposes, the costs of acquiring rights to land are recognized (Tax Code, Article 2641).

\section{Results}

So let's consider what value-added tax incentives are enterprises engaged in innovative activities., As follows from Art. 19 clause 26 of the Tax Code of the Russian Federation are not subject to VAT exclusive rights to inventions, computer programs, industrial designs, utility models, databases, etc.

The implementation of R\&D at the expense of the budget, as well as the work on the performance of R\&D by educational institutions and scientific organizations on the basis of business contracts, is not subject to VAT.

For organizations exempted from VAT, the tax burden is reduced, but organizations buyers who are tax payers, in this case do not have "input" VAT and include the amount of tax in the cost of purchased goods (works, services). It can be shown that it is more profitable for buyer organizations to purchase goods from sellers who are VAT payers.

We introduce the following notation:

B - revenue without VAT from the sale of goods (works, services);

$\mathrm{C}$ is the cost of sales;

$\mathrm{M}$ - the cost of the consumed materials (works, services);

$\mathrm{D}$ - part of the cost of sales, except for $\mathrm{M}$, so $\mathrm{M}+\mathrm{D}=\mathrm{C}$;

g - VAT rate;

$\mathrm{r}$ is the income tax rate. 
If an organization purchases materials from a supplier-payer of VAT, then the amount of tax payable to the budget for the tax period is $\mathrm{g}(\mathrm{B}-\mathrm{M})=\mathrm{gB}-\mathrm{gM}$, the amount of income $\operatorname{tax}$ is $r(B-C)=r(B-M-D)$.

If the materials were purchased from an organization that is not a VAT payer, then the amount of tax payable to the budget is $\mathrm{gB}$, the amount of income tax is $\mathrm{r}(\mathrm{B}-\mathrm{M}-\mathrm{D})$.

The amount of payments for VAT and income tax will be in the first case:

$$
g(B-M)+r(B-M)=(g+r) B-(g+r) M,
$$

in the second case :

$$
(g+r) B-r M
$$

Obviously, in the second case, the amount of payments is greater. For simplicity, the term D was omitted.

\section{Comclusion}

Thus, in order to stimulate innovation, it is advisable to tax the implementation of R\&D with value added tax at a rate of $0 \%$. This rate applies to exported goods when transporting passengers and goods across the customs border. At a zero rate, the organization does not pay VAT, but has tax deductions that can be used to pay other taxes.

\section{References}

1. W. Strielkowski, E. Volkova, L. Pushkareva, D. Energies 12(7), 1392 (2019).

2. I. Skvortsova, Y. Nurulin, MATEC Web of Conferences 170, 01004 (2018).

3. L. Pushkareva, O. Galochkina, O. Bezgacheva, Current trends in the banking system of Russia (2018)

4. T. Gorokhova, L. Pushkareva, M. Sredin, M. Pushkarev. E3S Web of Conferences 135, 04069 (2019). DOI 10.1051/e3sconf/201913504069.

5. J. P. Walsh, H. Huang, Research Policy 43(2), 245-260 (2014)

6. . A. Chunikhin, E. A. Kuzmin, L. V. Pushkareva, Entrepreneurship and Sustainability Issues 6(4), 1663-1679 (2019).

DOI:10.9770/jesi.2019.6.4(8)

7. Y. Chen, K. Ramamurthy, K. W. Wen, Journal of Management Information Systems 29(3), 157-188 (2012)

8. O. V. Voronkova, A. A. Kurochkina, I. P. Firova, T. V. Bikezina, Revista ESPACIOS 38(49), 29 (2017)

9. M. Orlova, A. Khafizova, Life Science Journal 11(11), 328-333 (2014).

10. V. Alpatov, MATEC Web of Conferences 86, 02020 (2016). DOI: $10.1051 /$ matecconf $/ 20168602020$

11. E. Cohen, EIB papers 11(1), 84-106 (2006) 
12. P. M. Senge, G. Carstedt, P. L. Porter, MIT Sloan management review, 42(2), 24-38 (2001)

13. E. M. Kryukova, E. A. Vetrova, A. N. Maloletko, O. V. Kaurova, S. V. Dusenko, Asian Social Science 11(1), 258 (2015)

14. D. Gliaubicas, Economics and management 17(1), 22-29 (2012).

15. S. Y. Bodrunov, Journal of New Economy 20(1), 5-12 (2019).

16. Y. V. Morozyuk, A. V. Sharkova, I. A. Merkulina, O. N. Vasilyeva, Journal of Environmental Management \& Tourism 8(3), 507-515 (2017)

17. H. Vasylevska, I. Novosad, A. Kovalenko, Contemporary Economy 9(4), 39-49 (2018).

18. O. Roy, Innovation and economic research 7(2), 7-17 (2019).

19. Y. B. Mindlin, S. V. Novikov, S. V. Kireev, A. A. Adamenko, O. V. Belitskaya, International Journal of Economics and Financial Issues 6(8S), 251-256 (2016) 